\title{
'Are You Fed up with Your PC? Get A Mac.' Swedish Popular Media Representations of Digital Technologies and the Stockpiling Behavior of Consumers
}

\author{
Jennie Olofsson \\ Correspondence: Jennie Olofsson, HUMlab, Umeå University 90187 Umeå, Sweden
}

Received: November 3, 2014

Accepted: November 19, 2014 Online Published: March 16, 2015

doi:10.11114/smc.v3i1.721

URL: http://dx.doi.org/10.11114/smc.v3i1.721

\begin{abstract}
This article offers a speculative reading on the linkage between Swedish popular media representations of digital technologies and peoples' stockpiling behavior. The hypothesis is that Swedish popular media representations of digital technologies contribute to fuelling an understanding of these technologies as resource-free, consumable goods, and that this in turn might affect peoples' tendencies to stockpile obsolete digital technologies in their homes. Previous studies have shown that stockpiling of obsolete electrical and electronic equipment is a common phenomenon in many countries (see for comparison Grossman, 2006; Saphores et al., 2006, 2009; Lescak, 2008; Gabrys, 2011). At the same time, little light is shed on why people stockpile obsolete electrical and electronic equipment in their homes. This article focuses particularly on digital technologies such as computers, televisions, smart phones, cell phones, laptops and tablets. Digital technologies are interesting as they account for a large - and increasing - amount of electrical and electronic equipment. Looking at the ways in which Swedish popular media represent digital technologies, this article suggests that popular media representations of digital technologies matter, not only in the ways people imagine and use digital technologies, but also the ways in which we think (or choose not to think) about their afterlife. The hypothesis is that the ways in which Swedish popular media represent digital technologies obstruct environmentally sound disposal and reuse options, something that in turn serves to cement and/or reinforce contemporary consumption behaviors and the environmental impacts that follow. By this, this article provides additional insights into what appears to be a western tendency to store obsolete electrical and electronic equipment at home.
\end{abstract}

Keywords: Swedish popular media, digital technologies, electronic waste, stockpiling, Swedish households

\section{Introduction}

\subsection{Stockpiling of Electrical and Electronic Equipment}

How many of us are currently stockpiling - not one or two, but several - outdated computers, televisions, smart phones, cell phones, laptops and tablets in drawers, closets, attics and basements? And how many of us lack sufficient arguments for why these devices continuously linger on in our homes? Previous studies have shown that stockpiling of obsolete electrical and electronic equipment ${ }^{1}$ is a common phenomenon in many countries (see for comparison Grossman, 2006; Saphores et al., 2006, 2009; Gabrys, 2011). In 2009, Jean-Daniel Saphores et al. (2009, 3330) estimated that of total amount of 747 million e-waste items were stored by US households, something that "suggests that the backlog of e-waste in the US may be much larger than generally believed".

Given that attitudes toward recycling are complex and vary between households (Miafodzyeva et al., 2013), little light is shed on why people stockpile obsolete electrical and electronic equipment in their homes. J-D Saphores et al. (2009, 3324) note that "as electronic products have gained in popularity, many households have stockpiled e-waste because they do not know how to safely and conveniently dispose of it". However, any explanation of why households lack knowledge of how to safely dispose of obsolete electrical and electronic equipment is not investigated further. A more

\footnotetext{
${ }^{1}$ Electrical and electronic equipment differ in that electrical equipment comprise of passive components such as resistors and inductors whereas electronic equipment, being equipped with active components such as semi conductors and transistors, can interpret a signal or an instruction and perform a task to suit the circumstances. Saying this, most electrical and electronic equipment today are equipped with both active and passive components.
} 
comprehensive understanding of the underlying reasons for why stockpiling occur is provided by Elizabeth Grossman (2006). In the book High-tech trash. Digital devices, hidden toxics, and human health (2006, 151ff) Grossman conducts a survey featuring twenty-six respondents. While limited in its range, the survey inquires, not only what kinds of electrical and electronic equipment are stockpiled, but also why these devices accumulate in the homes of the respondents. The answers vary, but Grossman $(2006,154)$ ultimately holds producers and retailers partly responsible for the delay in the e-waste stream, concluding that as "most high-tech electronics sold in the United States come without any information whatsoever about environmentally sound disposal and reuse options [...] getting rid of e-waste in a responsible way is a time-consuming endeavor even for conscientious consumers". By this, Grossman reaches similar conclusions as Saphores et al. as she emphasizes the scarce knowledge of households to explain accumulation of obsolete electrical and electronic equipment.

While Grossman refers to consumers in the US, her annotation is most relevant in a European context, and specifically with regards to the Waste Electrical and Electronic Equipment (WEEE) directive. The WEEE directive was incepted among EU member states in 2002 and aims to 1) prevent the emergence of e-waste, and 2) increase reuse, recycling of material and other types of recycling in order to decrease the disposal of e-waste. The symbol adopted by the European Council to represent WEEE comprises a crossed out wheelie bin, a symbol that clearly prohibits consumers to discard electrical and electronic equipment in the trash bin. At the same time, the crossed out wheelie bin does not offer any further information of what to do, something that partly obstructs environmentally sound disposal and reuse options.

\subsection{Stockpiling of Obsolete Electrical and Electronic Equipment in Swedish Households}

Internationally, Sweden is doing very well when it comes to recycling of waste electrical and electronic equipment. The WEEE directive requires at least four kilos of waste electrical and electronic equipment per person and year to be collected and recycled. In a report from The Swedish Environmental Protection Agency (Rapport 6536, 2012, 22) it is estimated that Swedish citizens recycle on average more than four times as much. While being at the forefront of collecting and recycling of waste electrical and electronic equipment, findings from El-kretsen, one of the two the business sectors companies for collection and recycling of waste electrical and electronic equipment, indicate that people in Sweden tend to stockpile obsolete electrical and electronic equipment in their homes, hence creating a huge delay in the e-waste stream. A study conducted for El-kretsen between 2011 and 2014 indicates that the computers that are handed in to the recycling stations today are ten years or older. The median age of CRT televisions are fifteen years, CRT monitors, thirteen years, cell phones are eight years (Berg, 2014). At the same time, interviewing a representative from MobilTeleBranschen: the trade association for suppliers, wholesalers and distributers in Sweden (2014-10-09), he informs that the average life span of a cell phone is 2, 3 years before rendered obsolete by newer models. This indicates a huge delay in the e-waste stream, but offers few explanations of why this happens. The Swedish Environmental Protection Agency's SMED Report No. 102, 2012 concludes that it is difficult to say anything about the amount of products that remains in peoples' lives, but no longer is in use (Hemström et al., 2012, 53). An interview with a representative for El-kretsen (2012-06-05) conforms to these studies: "no one works on a ten-year-old computer today, and it is only now that devices like this enter the electronic waste recycling stations". Saying this, more studies are needed in order to understand peoples' tendency to stockpile electrical and electronic equipment at home. Being a very technologically dense country (The Swedish Environmental Protection Agency Rapport 6536, 2012,22) with a high usage and early adoption of electrical and electronic equipment, Sweden is especially relevant for the purposes of this article. The high collection and recycling rate and the concurrent technophile that is said to characterize Sweden as well as many other Scandinavian countries, provide additional insights into what appears to be a western tendency to store obsolete electrical and electronic equipment at home.

\subsection{Hypothesis}

Returning to the studies of Grossman and Saphores et al., it is clear that additional studies are needed in order to understand why stockpiling occur. Methodologically, interviews have been used to identify peoples' discarding behavior when it comes to accumulation of consumer goods (see for comparison Gregson et al. 2007), something that facilitates a qualitative understanding of this phenomenon. However, other methods remain underdeveloped, particularly with regards to accumulation of obsolete electrical and electronic equipment. Informed by the works of Grossman and Saphores et al., and in order to find additional explanations for why households lack knowledge of how to safely dispose of obsolete electrical and electronic equipment, this article offers a speculative reading on the linkage between Swedish popular media representations of digital technologies such as computers, televisions, smart phones, cell phones, laptops and tablets and peoples' stockpiling behavior. Digital technologies are interesting as they account for a large and increasing - amount of electrical and electronic equipment. Previous research has investigated the agenda-setting function of mass media (see for comparison McCombs and Shaw 1972; Walgrave and Van Aelst 2006; Casero-Ripollés and López-Rabadán 2014), the indication being that mass media is "a key strategic resource in building public opinion (Casera-Ripollés and López-Rabadán 2014, 862). While it is clear that "the ability of media to set the political agenda is 
contingent on different variables and circumstances" (Casero-Ripollés and López-Rabadán 2014, 861), the correlations between media and public priorities cannot be disregarded: "when mass media emphasize a topic, the audience/public receiving the message will consider this topic to be important" (Walgrave and Van Aelst 2006, 89).

Informed by previous studies, I propose that popular media representations of digital technologies contribute to fuelling an understanding of these technologies as resource-free, consumable goods. The ways in which Swedish popular media represent digital technologies then, obstructs environmentally sound disposal and reuse options in that it elides information about how to manage their material residues. This in turn might encourage stockpiling behavior. In the chapter Out with the trash: On the future of new media (2007, 21), Jonathan Sterne notes that:

"New technology" conjures up well-lit images of sleekly designed computers and monitors; bright colors, spotless, smooth surfaces, clear screens, and quick applications. This obtains even though the average condition of computers is closer to dust-covered CPUs and monitors, screens dotted with fingerprints, and keyboards darkened by use"

Sterne's annotation does not only demonstrate the discrepancy between so-called new technologies and their material residues, it also points toward peoples' tendencies to stockpile these technologies in their homes - covered with dust and stored on top of cabinets - long after they are rendered obsolete.

\subsection{The Influence of Popular Media}

While it is difficult to specify the effects that media has on peoples' behaviors, the hypothesis of this article assumes a correlation between consumers' perception of digital technologies and the ways in which they are represented and framed within Swedish popular media. Above, I mentioned previous research that has investigated the agenda-setting function of mass media, especially with regards to politics. However, mass media does not only contribute to forming political agendas, it also affects our understanding of emerging technologies. One example of this is the book Make room for TV: Television and the family ideal in Postwar America (1992) in which Lynn Spigel shows how popular media in Post War America introduced the television to the public and how that affected the ways in which the television was used and imagined. Similarly, in their study Opening the black box: scientists' views on the role of the news media in the nanotechnology debate, A. Petersen, A. Anderson, S. Allan and C. Wilkinson $(2009,513 \mathrm{f})$ suggest that "in the case of emergent technologies, where there is considerable uncertainty as to their nature and implications, the question of how the news media frame issues during the early stages of their public visibility is likely to be crucial to audience perceptions [...]". In the study Daily newspapers' views on nanotechnology in Slovenia (2012, 31), B. Groboljsek and F. Mali too suggest that "The media has the function of a forum both reflecting and organizing broad public opinion".

The studies of Spigel, Petersen et al. and Groboljsek and Mali et al. are equally relevant to the purposes of this article as they show the ways in which popular media influence peoples' understanding of emerging technologies. Informed by these studies, this article argues that popular media representations of digital technologies matter, not only in the ways people imagine and use digital technologies, but also the way in which we think (or choose not to think) about their afterlife. In this particular case, the indication is that Swedish popular media representations of digital technologies play a major role in peoples' tendencies to stockpile digital technologies in their homes.

Having this said, the relationship between popular media representations of digital technologies and peoples' tendencies to stockpile obsolete digital technologies in their homes is far from straightforward. While media does play an important role in framing and representing certain phenomena, other factors equally contribute to stockpiling of obsolete digital technologies. I mentioned above Grossman's survey $(2006,151 \mathrm{ff})$ and the varied answers of her informants, including for example nostalgia but also intentions to give the old equipment to charity and to use old mobile phones and computers as a backup in case the new equipment should fail to work. As indicated, these explanations offer part of the reasons for the continued stockpiling of obsolete digital technologies. Interestingly, fifty percent of Grossman's informants also answer that they know that electrical and electronic goods should not be tossed in the trash, something that follows the same logic as the crossed out wheelie bin of the WEEE directive. Again, the lack of information affects what we do with outdated electrical and electronic equipment. Saying this, while previous research has focused on how media representations of new technologies affects public opinions this study is engaged with what is not represented and thereby elided. Put differently, the ambition is to critically scrutinize the ways in which Swedish popular media frame and represent digital technologies, and by this, identify some of the aspects that remain absent in this discussion.

\section{Material and Methodologies}

\subsection{Mediearkivet}

Looking at the ways in which Swedish popular media represent digital technologies, this article suggests that popular media matter for the ways in which digital technologies are anticipated, developed, introduced, reviewed, cherished and used, but more importantly stockpiled in Swedish households. The collection of contributions stems from the Swedish 
digital news and media archive Mediearkivet. Mediearkivet has to date approximately 25 million articles and dates back to January 1981. In order to match the years when Berg's (2014) study was conducted, this article investigates the years between 2011 and 2014. For comparative purposes, it also investigates the years of 1982 and 1999.

The archival investigation gave access to over 10000 news items: articles, chronicles, short announcements, contributions, reviews, and news reports from Swedish news agencies and newspapers as well as magazines with a direct focus on electronics. This article focuses specifically on reviews and consumer advices of digital technologies. The excerpts are all translations from Swedish to English. Any misspelling is the fault of the author.

\subsection{Selection of Keyword}

In order to cover as many digital technologies as possible, my ambition was to find a key word that would encompass and demonstrate the variety of digital technologies. I chose to use the search term 'screens', or 'skärmar' in Swedish. ${ }^{2}$ Screens are an interesting access point to digital technologies, as they are incorporated into an increasing number, not only of digital technologies, but also household appliances such as refrigerators, washing machines and stoves. Using the search term "skärmar" resulted in a good coverage of computers, laptops, televisions, mobile phones and cameras. While the contributions mainly discuss digital technologies in positive terms, the search result also included concerns for work-related injuries caused by digital technologies as well as contributions that discuss how to recycle digital technologies. Saying this, it should be mentioned that the search results generated by Mediearkivet do not provide an exhaustive picture of how digital technologies are illustrated in the Swedish popular press. While Mediearkivet covers the larger newspapers, magazines and journals in Sweden, it does not provide a complete account of Swedish popular media, something that affected the search results. In a similar vein, it is important to mention that the use of other search terms such as "computer", "television", "display" or "monitor" would have generated different search results. Moreover, the Swedish term "skärmar" ("screens") denotes both a noun and a verb, something that also affected the collection of material as the search term "skärmar" included these search results. As a verb, "skärmar" means shut off or shield. As a noun, screen also has different definitions, for example screens that are installed to dampen the noise from the traffic (bullerskärmar), as well as parachutes (fallskärmar), road signs (skärmar), controls for orienteers (skärmar) lampshades (lampskärmar), caps (skärmar) and mudguards (stänkskärmar) for bikes and cars. Using the search term "skärmar", these alternative definitions were generated, but not investigated further.

Given that the search results provided by Mediearkivet provide a partial picture of how digital technologies are discussed in Swedish popular press, they indicate a growing number of articles, chronicles, contributions, reviews, and news reports. In 1982, for example - the first year when the term screen is mentioned - five contributions were found on the search term "skärmar". In 1985, the number was twenty-eight and ten years later, in 1995, the number was almost three hundred (271). Saying this, a total hits of 2191 that were generated between 1982 and 2000 (a scope of eighteen years), to be compared with the 8451 hits between 2011 and 2014 (a scope of three years). This shows that the increased proliferation of digital technologies is paralleled by an exploding public interest.

\subsection{Critical Discourse Analysis}

Methodologically, and in order to pursue the textual analyses of the ways in which popular media represent and frame digital technologies, this article draws on critical discourse analysis (see for comparison Winther Jørgensen and Phillips, 2000; Mills, 2004). It doing so, it understands production and consumption of texts as an important form of the social practices that constitute the world (Winther Jørgensen and Phillips, 2000, 67). In this particular case, a critical discourse analytical perspective acknowledges the correlation between popular media representations of digital technologies and the activities of consumers. In what follows, I will demonstrate this correlation, arguing for a parallel between the popular media representations of digital technologies in terms of disembodied media and the amount of electronic trash that is stockpiled in households. A critical discourse analytical perspective also takes seriously, the ways in which power emerges and is sustained in and through production and consumption of texts, something that is equally relevant to the purposes of this article. As discourses are organized around practices of exclusion (Mills, 2004, 11), it is interesting to see the ways in which power emerges in and through certain popular media representations of digital technologies, and how other ways of talking about digital technologies are excluded as a result thereof.

\section{Discussion}

\footnotetext{
${ }^{2}$ Saying this, it is important to remember that computers have not always been equipped with a screen. In their article $A$ terminal condition: The Cathode Ray Tube's strange afterlife (2014) Josh Lepawsky and Charles Mather remind us that we initially communicated with computers through teletypes or punch cards. As CRT-monitors were introduced in American offices in the 1960 's, they radically changed the interface through which workers communicated with computers.
} 


\subsection{Commodification of Digital Technologies}

Studying the ways in which Swedish popular media frame and represent digital technologies, it is noteworthy that reviews and consumer advices of digital technologies do not emerge in Swedish newspapers until the mid 1990's, something that could be said to mark the start for the commodification of digital technologies. While reviews and consumer advices might be found in magazines that specifically focus on digital technologies, their absence in newspapers indicates that digital technologies remain unavailable (and not even thought of) as consumable goods until the mid1990's. Instead, in the beginning of the 1980's, digital technologies such as computers are discussed mainly in terms of working tools (see for example Tidningarnas Telegrambyrå 1982-06-20; 1983-11-15). They symbolize (scientific) work, professionalism and expertise, and are used particularly within the space industry, the airline industry and the maritime industry. This parlance functions both to introduce and alienate digital technologies from the everyday use of ordinary people. As digital technologies are connected exclusively to professional use they appear seemingly unrelated to the consumer market. At the same time, the reader is offered an insight to how digital technologies can serve beneficial to, for example the space industry, the airline industry and the maritime industry, something that serves both to distance the reader from the professional use of digital technologies and raise an awareness of their amazing capacities.

While digital technologies are continuously conveyed in terms of working tools during the 1990's, they are - as indicated above - also available to a general audience in that they are promoted in terms of consumable goods. Information about when new models are to be released, but also information about price, weight and size as well as resolution, memory, battery time and processors are examples of this. The altered parlance seems to serve as a self-fulfilling prophecy, and in the next couple of years, Swedish popular press features several reports on the increasing sale of digital technologies. The agency Tidningarnas Telegrambyrå (1992-04-28), for example, notes that:

'There are 1,5 million screens in Sweden and every year, 300000 new screens are bought.'

In March 1998, the magazine Dagens IT (1998-03-25) notes that:

'Last year, more than 5000 free standing flat screens were sold in Sweden. This number will more than double this year $[\ldots]$ '..

In September 1998, Dagens IT (1998-09-02) announces new estimations, suggesting that up to 20000 flat screens will be sold the year of 1998. In April 1999, the magazine Datateknik (1999-04-15) informs that the sale of computers increased by 55 percent during 1998, and in September 1999, Dagens IT (1999-09-15) informs that the sales of flat screens increased at an astonishing 927 percent during the first half of 1999.

Reports about the increasing sales of digital technologies are paralleled with reports on lower prices for flat screens as well as for stationary LCD screens (see for comparison Datateknik, 1998-05-07; Göteborgs-posten, 1998-08-20; Aftonbladet, 1998-09-27; Expressen, 1998-11-21). The combination of these reports and announcements of continuing price reductions conveys digital technologies in terms of consumable necessities. Noteworthy, focus is directed exclusively to the increasing sale of digital technologies. No information is provided on how many computers and flat screens that are discarded every year: a - one can imagine - natural consequence of their increased proliferation. Alienation from the afterlife of digital technologies might fuel hesitancy when it comes to how to adequately manage the material residues of digital technologies and thus contribute to stockpiling behavior.

\subsection{From Funky and Sexy to Curvaceous and Slender}

As digital technologies turn into commodities interest is to a larger extent directed to their physical design. From the mid 1990's, emerging customer advices and reviews do not only concern weight and size as well as resolution, memory, battery time and processors; the design of digital technologies also emerges as a prominent feature. The newspaper Dagens Industri (1990-05-08), for example, reports about the company Nokia being the world's first producer of color flat screens, and appoints this invention 'the world's most funky color flat screen'. In a similar vein, the newspaper Svenska Dagbladet (1995-09-02) rails against the design of current televisions, and uses expressions such as 'the clumsy and most often, ugly google box' - characteristics especially appointed to CRT televisions-to describe the striking lack of improvement when it comes to the design of screen technologies. The newspaper Aftonbladet (1998-09-27) uses terms such as sexy and cheeky to describe flat screens, characteristics that are said to attract the consumers. Dagens IT (1998-10-28), ultimately, uses terms such as "neat" to describe the company Multi Q's new computer.

Studying customer advices and reviews between 2011 and 2014, it is noteworthy that attention is continuously directed to the physical attributes of digital technologies. At the same time, new features are emphasized. The shift from CRT technique to LCD, LED, plasma and OLED technique for example, raises discussions regarding the thinness of computers and televisions, something that previously, and due to the CRT technique-appear irrelevant. Between 2011 and 2014, 
several reviews and customer advices mention thinness, and then often in terms of "razor blade ultra thin", as one of the most important competitive advantages (see for comparison Mölndals-Posten, 2011-03-02; PC-tidningen 2012-12-06; Västerbottens-Kuriren, 2012-12-06; M3, 2013-12-10).

The continuous emphasis on the physical characteristics of digital technologies indicates that computers, televisions, tablets and smart phones are seen as material objects rather than disembodied mediators. Reviews and consumer advices specifically use terms such as thin, light, slender, curvaceous small (and later on bendable) as well as big, clumsy, bulky and heavy to describe advantages and disadvantages with digital technologies. In case of the latter, solutions are sometimes provided for how to produce smaller, lighter, thinner or more integrated products. One example of this is the magazine M3's (2013-12-10) review of LG's curved 55-inch OLED-television. The title: "Smart, thin and curvaceous", summarizes the most advantageous features of this particular television, and in what follows attention is particularly directed to the thinness of the television: "The oled technique means among other things that this TV is extremely thin. At its thinnest, it measures only 4, $5 \mathrm{~mm}$ ". The review goes on to argue that the OLED technique does not only allow for thin and curvaceous screens; as the television is not backlit, the image contrast increases, something that in turn enhances the viewing experience. Saying this, critique is raised regarding the plastic rack for cables that is mounted at the back of the television as well as the clumsy stand as it adds to the thickness of the television and obstructs smooth wall mounting. The built-in loud speakers on the other hand, are much appreciated, precisely because they are built-in, thus integrated into the television and thereby also (partly) rendered invisible. This is to be compared with the plastic rack and the stand: material components that appear as inconvenient add-ons and (at least with regards to the latter) obstructs smooth wall mounting.

At the same time as reviews and consumer advices cherish features such as neat, thin and curvaceous, the practical implications of these features are rarely outlined. One exception is Expressen's (1993-03-14) review of the newly emerging, referred to, portfolio computers and the subsequent comparison with stationary computers. Here it is noted that:

'The portfolio computer might also be the perfect home computer. It does not occupy much place, it does not have a noisy fan and it can easily be tucked away in the wardrobe when not in use.'

Expressen's emphasis on the possibility to tuck away the portfolio computer in the wardrobe indicates not only convenient usage; it also hints toward the ways in which increasingly smaller and slimmer digital technologies allow for stockpiling in ways that were not possible before. Stockpiling behavior then, can be seen as the unthought-of side effect of the increased proliferation of flat screens in general and portfolio computers specifically.

\subsection{Digital Technologies and the Future}

While the illustrations of digital technologies in the Swedish popular press change between the years of 1982 and 2014, digital technologies continuously seem tantamount to the future. Already in the 80's, digital technologies, and then in terms of liquid crystal displays (LCDs), plasma screens and touch screens, are mentioned (see for comparison Tidningarnas Telegrambyrå 1982-10-26, 1985-04-16, 1985-12-20). In 1993, the newspaper, Dagens Nyheter offers 'A snapshot into the future' (1993-12-31). Here, the reader is informed about the upcoming transition phase from 1994 1998 where mechanic thinking will be replaced by electronic thinking. By the end of 1994, the newspaper Expressen's contribution "At home in the future" (1994-10-22), features an imagined cooking scenario in order to illustrate what today would be referred to as smart homes:

'Within five to ten years, we will have computers, screens and video phones in every room at home [...]'

Dagens Industri (1996-01-20) adopts a similar parlance, featuring an imagined everyday conversation. This report also directly addresses the reader:

'How far did you jog today? 7416 meters - if you want to see my track profile, I can show it on the pocket computer?'

The imagined conversation above fosters an intimacy between digital technologies, in particular screen technologies, and the consumer. Screen technologies are not only part of everyday conversation; they also facilitate and enhance practices such as jogging and, as seen above, cooking. This serves to reinforce familiarity as well as simplicity.

Similar to many of the concurrent reports, Aftonbladet (1999-12-27), offers a visionary outline of future use of computers: Science fiction? Not for much longer'. This report also addresses the reader, featuring an imagined everyday occurrence from the future:

'You wallow on your favorite couch and bang, the latest world news is projected on a thin screen on the wall. A list containing the scheduled meetings today flashes by on your portable monitor that is integrated in your glasses.'

It is noteworthy that between the years of 1982 and 2000, the more recent futuristic accounts directly address the reader and (more importantly) the consumer in terms of You, alternatively use terms such as We or Us to emphasize digital technologies in terms of consumable, and more specifically, common goods. The future is also explicitly associated 
with everyday activities such as cooking and jogging, activities that are (assumed to be) known to the reader. The use of well-known activities serves to stipulate codes of conducts for what kind of future behaviors that are desirable. For example, while the reader is seen wallowing on her/his favorite couch, s/he is at the same time expected to simultaneously check e-mails and plan future meetings.

From the mid 1990's the futuristic accounts are paralleled (and later on merged) with practical consumer tips and reviews of specific products and models in which the magazine guides the user to make the right choices, a rhetoric that also characterizes reviews and consumer advices between the years of 2011 and 2014. Saying this, while reviews and consumer advices focus on digital technologies as common goods, they fail to take into account their material residues, something that in turn serves to legitimize the increasingly rapid consumption of digital technologies. Instead, focus is directed to digital technologies as mediators of what is continuously referred to as the future. The magazine Computer Sweden (2011-03-25) for example, reports on the upcoming conference Screen 2011, an event that focuses on the increased use of screens. The conference gathers experts, analysts and visionaries to examine contemporary usages of screens and discuss future strategies for screen usage. The assumption is that "In the future, the presence on the screens will be even more important”. Similarly, Expressen (2012-01-23) reports from CES, the home electronics' fair in Las Vegas where focus is on screens. The title: "A screen course for future television", assumes an educational tone where the reader is informed about the multiple usages of future screens.

"Not only are screens becoming bigger (and smaller) with higher resolution; they are becoming more and more numerous and are available in sizes suitable for any kind of occasion."

The report focuses specifically on the ways in which the entertainment industry affect, and is reversely affected by new ways of watching television on computers, tablets, and smart phones as well as through on-demand services. As the amount of screens is increasing and their format covers computers, televisions, tablets and smart phones, the entertainment industry continuously looks for new ways of applying to consumers. Here, screens figure exclusively as mediators, facilitating future strategies for screen usage.

While the news items are written within a long period of time, it is noteworthy that they formulate similar ideas of how the future will look like: surrounded and enhanced by screens, digital glasses and pocket computers. The future then, is conveyed as one rather than many: clean, efficient, resource-free and unbound by accumulation of yesterday's high-tech devices. Anything that falls outside of this scenario is rendered invisible, including the increasing speed with which digital technologies are replaced and rendered obsolete. This in turn might contribute to hesitation regarding processes of discarding.

\subsection{Digital Technologies as Consumable Goods}

Between the years of 1982 and 2000, reviews and customer advices explicitly pinpoint digital technologies as consumable goods, and more specifically in terms of "consumable electronics" (see for comparison Svenska Dagbladet, 1999-09-26; Datateknik, 1999-10-04). Svenska Dagbladet (1999-09-26), for example states that:

'Plastic cutlery, plastic cups and plastic bags; consumable goods that we have learned to use and throw away. Now, the next product in the disposable society appears: consumable electronics. Made out of plastics of course. The Dutch [company] Phillips has developed a method to produce transistors, completely in plastics.'

Aftonbladet (1999-11-01) too, embraces the thought of consumable electronics, asking the reader:

'Are you fed up with your pc? Get a Mac. Are you done with Mario? Change games'.

While reviews and customer advices between the years of 2011 and 2014 do not use the same explicit language to convey digital technologies in terms of consumable goods, they strikingly illustrate and legitimize the increasingly rapid consumption patterns, partly by using expressions such as "fed up with", and "must-have". The newspaper Värmlands Folkblad (2011-01-29) for example, lists "eight cool computers - for those of you who are fed up with your normal PC". These seemingly simple acts of exchange however say little or nothing about the environmental impacts that follow. As the name implies, consumable electronics are made to be consumed, and more importantly, disposed of when replaced by newer models. The acts of disposal however, are not outlined further.

As digital technologies are framed and represented in terms of consumable goods, reviews and customer advices particularly emphasize the importance of smooth installations and usages of digital technologies as well as user-friendliness, intuitive interfaces and simple operations. PC-tidningen's (2013-12-23) review of MSI's new model AE200 for example, praises the integrated computer and screen, an all-in-one solution that is said to facilitate easy installation and placement. Another example is the magazine Ljud \& Bild's (2013-12-10) review of LG's G Pad 8.3 where focus is on the intuitive touch functions. PC för alla (2012-01-13) examines Viewsonic's new model V3D245 and appreciates particularly the ease with which to install the stand. The title: "3D screen without hassle", conveys smoothness and indicates that digital technologies should not provide too many complications. Similarly, the magazine 
PC-tidningen's (2012-12-06) review of the new iPhone 5 mentions the super simple operating system as one reason for the highly ranked phone. In another of PC-Tidningen's reviews (2013-12-23) focus is directed to the many complications that the test panel had to go through before they were satisfied with the quality of the image: "We had to tamper with the clarity-, color-, contrast-, and light adjustments for quite some time before we were satisfied".

Not only are digital technologies themselves requested as uncomplicated; a review in the magazine PC för alla (2011-02-21) explains the practice of paying tv-licence in terms of an inconvenience that can be avoided by purchasing one (or several) of the computers that are part of the review. Simplicity then, extends to the surrounding infrastructures, at the same time as the review renders these infrastructures inconvenient, and to preferably be avoided. In sum, appreciating the simplicity of digital technologies might contribute to an understanding of digital technologies in terms of consumable goods. Televisions, computers and smart phones should facilitate easy set-ups; focus is on smooth usages and intuitive interfaces rather than advices of how to maintain, repair and recycle. This in turn contributes to distancing the reader from the material residues of digital technologies. As Sterne $(2007,27)$ has it: "If users can ignore their own computer trash once it leaves the home or office, it becomes much easier to maintain an image of computers as new media". As this image to a large extent is conveyed in and through media, the correlations between media and public priorities cannot be disregarded.

\subsection{Environmental Concerns}

The above sections have shown how Swedish popular media illustrates digital technologies alternately as professional tools and pleasurable toys, common goods and dreamlike devices, valuable assets and consumable goods that facilitates easy installations and intuitive interfaces. Despite the disparate discursive meanings that are allocated to digital technologies, it is noteworthy that the above contributions exclusively convey them in terms of high-tech devices and also tantamount to the future. As a result other ways of talking about digital technologies are excluded. Saying this, the apparent lack of relation between digital technologies and their material residues points toward a discursive mismatch where contemporary consumption behavior and the subsequent production of digital technologies are cemented and/or reinforced. This leaves concerns of what happens to digital technologies as they are discarded or rendered obsolete largely unanswered.

Drawing on the above examples, it is evident that consumption of digital technologies appears as "a natural, God-given freedom" (Maxwell and Miller 2012, 41). As such digital technologies are seemingly dis-connected to processes of discarding. Informed by a critical discourse analytical perspective, the focus of Swedish popular media on digital technologies as resource-free, consumable goods evolves in the exclusion of any critical account of their afterlife. This is valid, not only for the afterlife of digital technologies, but more importantly for the understanding of digital technologies as always already trash. As Jonathan Sterne $(2007,17)$ has it: "The entire edifice of new communication technology is a giant trash heap waiting to happen [...]"

Shortly returning to the absence of critical accounts, while environmental concerns do exist, any critical understanding the environmental implications of the increased proliferation of digital technologies is limited to letters to the editor or shorter notices in newspapers. One example is the newspaper Svenska Dagbladet (2012-01-23) where Henrik Nilsson, founder and chairperson of Inrego, publishes a letter to the editor. Inrego is a Swedish company that specializes in reconditioning and selling used IT equipment. The title of the item: "Stop the throwaway mentality with regards to it equipment", offers an alternative understanding of digital technologies as it points toward their material residues. A couple of days earlier, the newspapers Borås Tidning (2012-01-18) and Helsingborgs Dagblad (2012-01-18) too, reason around current consumption patterns of digital technologies and the throwaway society. Their accounts draw on an investigation conducted by Inrego, and Borås Tidning also features an interview with Nilsson. Here, Nilsson states that the large amount of computers that are currently discarded is not only to be understood as an economic waste; it is also objectionable from an environmental perspective.

As opposed to reviews and customer advices, letters to the editor are framed as explicitly subjective; they are conveyed in terms of opinions as opposed to the (objective) news items. By this, the latter lack the authority that is given to reviews and customer advices. While both reviews and customer advices and letters to the editor adopt an informal parlor - the authors address themselves in terms of "I", "we", and "the testpanel" - the educational tone that pervades reviews and customer advices indicates a neutral distribution of knowledge.

Apart from letters to the editors and shorter news items, the only time that concerns are raised regarding the environmental impacts of digital technologies is in relation to low energy consumption, something that, critically, has more to do with saving money than worrying for the environment. The review in the newspaper Norra Västerbotten (2012-01-03) for example, discusses Phillips' Ecomova, a LED television that is launched in terms of "both green and smart". This is due to its low energy consumption, the lack of pvc plastics and flame retardants as well as the solar energy powered remote control. In the initial text however, economical reasons for why the customer should choose this 
particular television take precedence over any environmental concern. While the LED television to a certain extent might be said to pass as more environmentally friendly than other models, the review does not offer any consumer advice of how to manage its material residues. Saying this, one might argue that the one-sided focus on acquisition and consumption of digital technologies rather than processes of discarding lays in the very nature of reviews and consumer advices. From a critical discourse analytical perspective however, it is important to remember that the outline of reviews and consumer advices also excludes alternative ways of discussing digital technologies.

\section{Conclusion}

This article has provided a speculative reading on the linkage between Swedish popular media representations of digital technologies and peoples' stockpiling behavior. Informed by previous research, it is clear that households lack knowledge of how to safely dispose of obsolete electrical and electronic equipment, and the current aim has been to explore some of the possible reasons for why this is. The suggestion is that households' behavior when it comes to stockpiling of obsolete digital technologies is - in part - the effect of a) the lack of information about how to discard of obsolete digital technologies, and b) the ways in which digital technologies are represented and framed within Swedish popular media. While previous research has focused on how what is emphasized in media also contributes to forming the public agenda, this article has demonstrated that it is exactly popular media's lack of focus on the environmental impacts of digital technologies that partly contribute to the delay in the e-waste stream.

The above reviews and consumer advices are examples of how power emerges in and through popular media representations of digital technologies, and how that in turn contributes to alienate consumers of computers, televisions, smart phones, cell phones, laptops and tablets from their material residues. Drawing on the work of Sterne $(2007,28)$, while the cutting-edge technologies that are represented in popular media are "built [...] with an eye toward their own replacement", the very consequences of these frequent acts of replacement is less evident, at least when studying Swedish popular media.

Drawing on a critical discourse analytical perspective, this article has investigated the ways in which power emerges in and through certain popular media representations of digital technologies, and how other ways of talking about digital technologies are excluded as a result thereof. Paraphrasing Sara Mills $(2004,11)$, the particular representation of digital technologies, as put forth by the Swedish popular press, is made possible by the fact that other ways of understanding digital technologies have been excluded. As reviews and consumer advices (re)present digital technologies alternately in terms of professional tools and pleasurable toys, common goods and dreamlike devices, valuable assets and consumable goods that facilitates easy installations and intuitive interfaces, any notion of digital technologies as resource intense objects and/or hazardous waste is expelled.

In the book Always already new. Media, history, and the data of culture (2008), Lisa Gitelman offers an historical account of the materiality of media. With regards to old media, Gitelman $(2008,4)$ pinpoints their status as "unacceptably unreal". Their status as old also assumes their inability to do the job anymore, a job, Gitelman continues, that "is largely though not exclusively one of representation". Studying reviews and customer advices, and informed by the work of Gitelman, it is clear that the job of digital technologies is conveyed exclusively in terms of representation and mediation, something that aggravates for consumers to think about digital technologies outside of their mediating functions. The indication is that the increased proliferation of digital technologies and their environmental impact appear largely unrelated, something that is acknowledged by Richard Maxwell and Toby Miller (2012). At the same time, '[a]ssessing the volume of e-waste, it is important to consider the rapid rate at which high-tech electronics have proliferated' (Grossman, 2006, 143).

The works of Maxwell and Miller and Grossman properly capture the main ambition of this article. Studying the ways in which Swedish popular media frames and represents digital technologies, this article has sought to show how their shifting status spurs radically distinct ways of reasoning, something that in turn serves to cement and/or reinforce contemporary consumption behaviors and the environmental impacts that follow. I have argued that in order to understand peoples' tendencies to stockpile obsolete digital technologies at home, one has to investigate the popular media representations of digital technologies. The bliss of digital technologies as depicted in popular media, gives little or no advices of what to do with its material residues.

\section{Acknowledgements}

This research was supported by the Knut and Alice Wallenberg Foundation through the 'Media Places' Research Program (part of the Wallenberg Network Initiative that supports collaboration between Umeå University and Stanford University).

\section{References}

Avfallsstatistik för bättre miljöarbete. En utvärdering av dataförsörjningen till avfallsstatistiken. Rapport 6536 (2012). 
Berg, P. E. O. (2014). Sammanställning av data insamlade på uppdrag av el-kretsen 2011-2014. Unpublished.

Casero-Ripollés, A., \&López-Rabadán, P. (2014). Media engagement boundaries and political influence in Europe. American Behavioral Scientist, 7, 859-868.

Gabrys, J. (2011). Digital rubbish: A natural history of electronics. Ann Arbor: The University of Michigan Press. http://dx.doi.org/10.3998/dcbooks.9380304.0001.001

Giannoulis, C., Skanavis, C. \& Karapatsiou, E. (2014). Environmental awareness: Environmental accidents as an example to be avoided. A summative international analysis. Studies in Media and Communication, 2, 38-48. http://dx.doi.org/10.11114/smc.v2i1.334

Gitelman, L. (2008) Always already new. Media, history, and the data of culture. Cambridge and London: MIT Press.

Gregson, N., Metcalfe, A., \& Crewe, L. (2007). Identity, mobility and the throwaway society. Environment and Planning: Society and Space, 25, 682-700. http://dx.doi.org/10.1068/d418t

Groboljsek, B., \& Mali, F. (2012). Daily newspapers'views on nanotechnology in Slovenia. Science Communication, 34, 30-56. http://dx.doi.org/10.1177/1075547011427974

Grossman, E. (2006). High tech trash. Digital devices, hidden toxics, and human health. Washington, Covelo and London: Island Press.

Hemström, K., Stenmarck, Sörme, L., \& Carlsson, A. (2012). Kartläggning av flöden och upplagrade mängder av elektriska och elektroniska produkter i Sverige 2010. A report completed for The Swedish Environmental Protection Agency's SMED Rapport Nr 1022012

Lepawsky, J., \& Mather, C. (2014). A terminal condition: The Cathode Ray Tube's strange afterlife. The Atlantic.

Lescak, S. (2008). Waste of Technology. Proceedings of MFD 2008, Karlstad University, Sweden.

Maxwell, R., \& Miller, T. (2012). Greening the media. Oxford, New York, Auckland, Cape Town, Dar es Salaam, Hong Kong, Karachi, Kuala Lumpur, Madrid, Melbourne, Mexico City, Nairobi, New Delhi, Shanghai, Taipei and Toronto: Oxford University Press.

Miafodzyeva, S., Brandt, N., \& Andersson, M. (2013). Recycling behaviour of householders living in multicultural urban area: a case study of Järva, Stockholm, Sweden. Waste Management \& Research, 31, 447-457. http://dx.doi.org/10.1177/0734242X13476746

McCombs, M. E., \& Shaw, D. L. (1972). The agenda-setting function of mass media. The Public Opinion Quarterly, 2 , 176-187, http://dx.doi.org/10.1086/267990

Mills, S. (2004). Discourse. London and New York: Routledge.

Petersen, A., Anderson, A., Allan, S., \& Wilkinson, C. (2009). Opening the black box: sceintists' views on the role of the news media in the nanotechnology debate. Public Understandings of Science, 18, 512-530. http://dx.doi.org/10.1177/0963662507084202

Saphores, J. D, M., Nixon, H., Ogunseitan, O. A., \& Shapiro, A. A. (2006). Household willingness to recycle electronic waste. An Application to California. Environment \& Behavior, 38, 183-208. http://dx.doi.org/10.1177/0013916505279045

Saphores, J. D, M., Nixon, H., Ogunseitan, O. A., \& Shapiro, A. A. (2009). How much e-waste is there in US basements and attics? Results from a national survey. Journal of Environmental Management, 90, 3322-3331. http://dx.doi.org/10.1016/j.jenvman.2009.05.008

Spigel, L. (1992). Make room for TV: Television and the family ideal in Postwar America. Chicago and London: The University of Chicago Press. http://dx.doi.org/10.7208/chicago/9780226769639.001.0001

Sterne, J. (2007) Out with the trash: On the future of new media. In: Residual Media. Editor Charles R. Acland. Minneapolis: University of Minnesota Press

Walgrave, S., \& Van Aelst, P. (2006). The contingency of the mass media's political agenda setting power: Toward a preliminary theory. Journal of Communication, 56. 88-109. http://dx.doi.org/10.1111/j.1460-2466.2006.00005.x

Winther Jørgensen, M., \& Phillips, L. (2000). Diskursanalys som teori och metod. Lund: Studentlitteratur.

\section{Articles}

Aftonbladet (1998-09-27) Prisras på platta skärmar - 20000 kronor billigare - bara i år

Aftonbladet (1999-11-01) Nygammal nalle eller billigt bläck? 
Aftonbladet (1999-12-27) Hjälp, datorn kan ta makten.

Borås Tidning (2012-01-18) Felfria datorer blir skrot.

Computer Sweden (2011-03-25) Screen 2011 - En konferens om framtiden pa skarmarna [sic]

Dagens Industri (1990-05-08) Nokia först med platt färgskärm.

Dagens Industri (1996-01-20) Morgondagens IT-teknik snart vardagsmat

Dagens IT (1998-03-25) Dubbelt upp för platta bildskärmar

Dagens IT (1998-09-02) Tredubbling spås för platta bildskärmar

Dagens IT (1998-10-28) MuliQ:s nya: snygg men dyr

Dagens IT (1999-09-15) Marknaden går Multi Q:s väg

Dagens Nyheter (1993-12-31) En blick in i framtiden

Datateknik (1998-05-07) Korta nyheter

Datateknik (1999-04-15) Datorförsäljningen upp 55 procent 1998

Datateknik (1999-10-04) Notiser

Expressen (1993-03-14) Lilldatorn blir stor

Expressen (1994-10-22) Hemma i framtiden

Expressen (1998-11-21) Dags för ett nytt systemkrig?

Expressen (2012-01-23) En skärmkurs för framtidens tv

Göteborgs-posten (1998-08-20) Priset på platta skärmar sjunker

Helsingborgs Dagblad (2012-01-18) Många gamla datorer slangs ofta helt i onödan

Ljud \& Bild's (2013-12-10) Pioneer tillbaka med TV

M3 (2013-12-10) Årets 100 coolaste prylar

MacWorld (2013-12-10) Äntligen retina i nya iPad mini

Mölndals-Posten (2011-03-02) Vårens coolaste datorer - 6 datorer och skärmar som sticker ut

PC för alla (2011-02-21) 6 "TV-skärmar" testas. 27-tummarna som inte kräver tv-avgift

PC för alla (2012-01-13) 3d-skärm utan krångel

PC-tidningen (2012-12-06) Den bästa iPhonen - iPhone 5

PC-tidningen (2013-12-23) Allt i ett med reflexfri skärm

Norra Västerbotten (2012-01-03) 8 apparater för soffsurfare

Svenska Dagbladet (1995-09-02) Dags igen för vägg-TV

Svenska Dagbladet (1999-09-26) Ledande plast ger hoprullbar bildskärm

Svenska Dagbladet (2012-01-23) Stoppa slit- och slängmentaliteten med it-utrustning.

Tidningarnas Telegrambyrå (1982-06-20) Rymd

Tidningarnas Telegrambyrå (1982-10-26) Skärmnytt

Tidningarnas Telegrambyrå (1983-11-15) Säkert

Tidningarnas Telegrambyrå (1985-04-16) Skärm

Tidningarnas Telegrambyrå (1985-12-20) bildskärmnv

Tidningarnas Telegrambyrå (1992-04-28) Självsläckande bildskärmar spar pengar och förbättrar arbetsmiljön.

Värmlands Folkblad (2011-01-29) Här är vårens coolaste datorer

Västerbottens-kuriren (2012-12-06) Lätt, nätt och tillplattat

\section{(cc) BY}

This work is licensed under a Creative Commons Attribution 3.0 License. 